NEWS

\title{
US stem-cell research expands
}

Nearly 11 years after Wisconsin-led researchers reported the first isolation of human embryonic stem cells, the field became eligible this week for broad research funding by the US government.

In final guidelines that went into effect on 7 July, the National Institutes of Health (NIH) established a process that will allow scientists who hold stem-cell lines derived before this date to apply for their inclusion in an agencyestablished registry of fundable cell lines.

In doing so the agency, based
"The NIH has done what is best for the field by having their own registry - one list that everyone can work from." draft guidelines, "it became clear that there were lines that responsible people would all agree were responsibly derived ... but might not meet the exact guidelines that we have put forth," said Raynard Kington, acting NIH director, on 6 July.

A working group will be established to judge on a case-by-case basis whether pre-existing lines "meet the principles underlying the guidelines", he said.

Those principles remain unchanged from the April draft: fundable lines must be derived from embryos that were created in Bethesda, Maryland, acknowledged that the strict ethical conditions it laid out in draft guidelines published in April (see Nature 458, 950-951; 2009) may have excluded many existing cell lines from federal funding. After receiving more than 49,000 comments on the solely for reproductive purposes and are no longer needed. Parents must voluntarily donate the embryos without inducements or researcher influence, and written informed consent must be obtained.

The final guidelines, like the draft ones, exclude funding for stem cells derived from embryos created for research, whether by in vitro fertilization, somatic cell nuclear transfer or parthenogenesis, when an unfertilized egg is developed into an embryo.

Although lines created in the United States from 7 July onwards will have to follow the guidelines to the letter, scientists who create lines abroad in future may apply to the working group to demonstrate that a line was made under procedural standards that are "at least equivalent" to those provided in the final guidelines. The NIH director will give the final approval to all decisions made by the group.

Kington said he expected the group to comprise nine to ten people, including ethicists, scientists and fertility doctors, and to be up and running "within the next couple of months", along with the new registry.

Many scientists were delighted with the final guidelines. "It's a huge step forward,"

\section{Flu jabs urged for developing countries}

SIENA

Influenza experts are recommending an extensive vaccination programme against seasonal flu in developing countries, in part to boost demand for vaccines so that firms can ramp up production to cope with pandemics. The message came from scientists and policy-makers who met on 2-3 July in Siena, Italy, to assess the gaps in their knowledge about the current H1N1 pandemic virus.

The governments of many developing countries remain to be convinced that flu is a major danger for their citizens relative to other health problems, says Abdullah Brooks of the International Centre for Diarrhoeal Disease Research in Dhaka, Bangladesh. Yet Brooks presented research showing that around one-third of pneumonia deaths in children younger than 2 years old in his region can be attributed to the influenza virus. According to the United Nations agency UNICEF, pneumonia kills more than 2 million children under the age of five each year - more than any other disease.

At the meeting, experts

recommended that pilot studies be conducted in developing countries to measure the prevalence of flu virus in sick children, and to assess how much a flu-vaccination programme would reduce the burden of disease in the countries. UNICEF, health charities and the governments of rich nations would probably be approached for financial support.

As well as providing a major public-health benefit, the effort could create a larger, more stable market for seasonal flu vaccines in the future. "A few months ago we were discussing whether we would need to close some of our manufacturing plants because we were losing so much money on flu vaccines," says Rino Rappuoli, head of vaccine research at Novartis in Siena, adding that the current H1N1 pandemic has helped to avert any closures as governments race to stock up on vaccines. For example, the firm was awarded US $\$ 289$ million by the US Department of Health and Human Services (HHS)

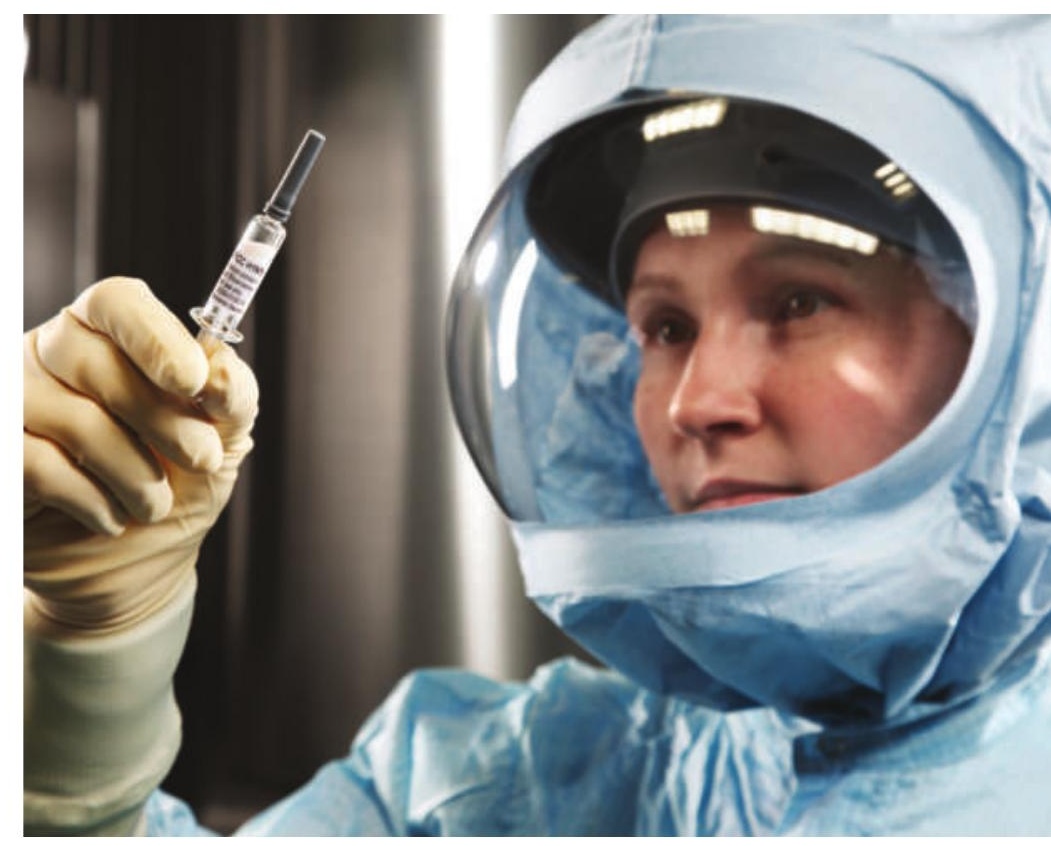

Boosting demand could help vaccine manufacturers keep their facilities open.

in Bethesda, Maryland, in May to produce $\mathrm{H} 1 \mathrm{~N} 1$ vaccine antigen as well as an adjuvant to amplify the immune response to the vaccine, thus reducing the amount of antigen needed in each shot and stretching manufacturing-plant capacity. Other vaccine companies, including GlaxoSmithKline, Sanofi Pasteur, CSL Biotherapies and Medlmmune, will also benefit from $\$ 643$ million in HHS orders. 
says George Daley, a researcher at Children's Hospital Boston and the Harvard Stem Cell Institute in Cambridge, Massachusetts. "It's flexible and science friendly."

Sean Morrison, a stem-cell biologist at the University of Michigan in Ann Arbor, adds: "The NIH has done what is best for the field by having their own registry - one list that everyone can work from."

Some scientists, including Daley, said that they were disappointed with the exclusion of embryos derived for research purposes, but pointed out that the agency intends to revisit the guidelines as the science evolves.

The NIH guidelines depart in one significant way from existing National Academy of Sciences standards; they do not require consent from gamete donors - only from the couple seeking in vitro fertilization services.

The guidelines respond to an executive order issued in March by President Barack Obama (see Nature 458, 130-131; 2009), who lifted restrictions imposed by President George W. Bush on 9 August 2001.

Meredith Wadman

The US Food and Drug Administration (FDA) has yet to approve any flu vaccines that contain an adjuvant, a cautious response to the possibility that adjuvants could trigger autoimmune disease on very rare occasions. Yet in 2000, the European Medicines Agency approved Novartis's seasonal flu vaccine Fluad, which contains MF59 - an adjuvant based on squalene, a complex hydrocarbon that is the biochemical precursor to steroids. Novartis says that it has sold 45 million vaccination shots containing MF59, and that no side effects have been reported other than occasional inflammation at the injection site. "It isn't really clear what additional safety data the FDA could be waiting for," says Peter Palese, a virologist at Mount Sinai School of Medicine in New York. And a study published earlier this year has shown that MF59 can broaden the effectiveness of an H5N1 vaccine to tackle several similar viral strains - an effect that could potentially be applied in H1N1 vaccines as well (G. Galli et al. Proc. Natl Acad. Sci. USA 106, 7962-7967; 2009).

The consensus of the meeting was that H1N1 vaccines, which could be given to billions of people this year, should contain an adjuvant. These vaccination programmes will provide a unique opportunity to identify any extremely rare side effects, says virologist Albert Osterhaus of the University of Rotterdam, the Netherlands, as long as they have "mechanisms to monitor all cases of autoimmune disease to see if the vaccine is really to blame."

Alison Abbott

\section{Czech researchers angry over government changes}

Scientists in the Czech Republic are up in arms over drastic changes in the national science-funding system that they say will damage basic research in the long term.

Starting next year, core funding for Czech universities and research institutes will be allocated according to rigorous metrics. Institutes can obtain 'points' for a variety of publications and for patents, but also for any software, methods, samples, prototype devices and 'validated technologies' developed in-house. The government plan, drawn up over the past three years with the goal of increasing the efficiency of research and development, was

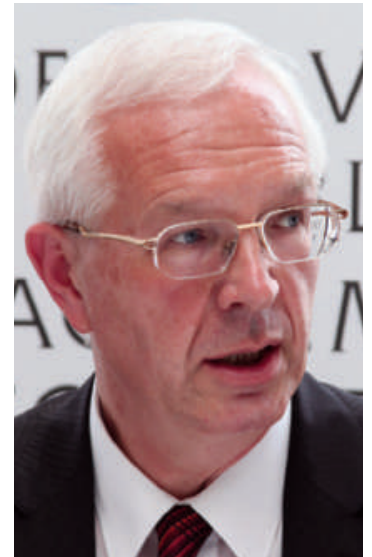

Jiří Drahoš fears that budgets will be cut still further. cannot work anymore."

At a crisis meeting last week, the academy's leadership decided to stop paying for repairs and procurement, including purchasing scientific equipment, starting in January. If budgets continue to decline, staff may have to be laid off, says Drahoš.

The reform comes from a council chaired by Jan Fischer, the Czech prime minister, and comprising representatives from universities, the academy and industry. Initially, applied and industryoriented research were supposed to be strengthened without affecting basic research. Changes included reallocating science portfolios to the industry ministry and creating a new technology agency.

The government had said previously approved by the Czech cabinet on 29 June.

But critics say that the prescribed funding formula gives a grossly distorted picture of the real assets of Czech science, and threatens to destroy its best parts. Ill-defined criteria of 'innovation' will downgrade the merit of detailed work on books and peer-reviewed papers, they argue, while rewarding impressivesounding concepts and rushed patent applications.

"One general formula for all branches of science?" says Jan Konvalinka, a group leader at the Academy of Sciences of the Czech Republic's Institute of Organic Chemistry and Biochemistry in Prague. "That's almost alchemy."

The academy, which runs 54 basicresearch institutes, will be hit badly. In 2010, it will lose 1 billion Czech koruny (US\$54 million), or about $20 \%$ of its annual budget, as a result of the new scheme. Academy president Jiř́i Drahoš says that in future years the number could climb to $45 \%$ of the value of the current budget.

"If this new formula is strictly applied, we will enter into a liquidation spiral," he says. "At some point the academy just that public-science budgets would increase by 2 billion koruny per year, to 31 billion in 2012. But the economic crisis has thwarted the plan, and science expenditure is now frozen at 25 billion koruny per year.

The freeze follows several prosperous years for Czech science, which has experienced a notable upswing since the country entered the European Union (EU) in 2004: it now spends around $1.4 \%$ of its gross domestic product, up from $1.2 \%$ in 2003, on research and development. This is more than any other formerly socialist, eastern European country in the EU.

Critics say that the new system is a step backwards. "It started out as a good idea, but then it got screwed up in the hands of technocrats," says Pavel Jungwirth, a computational chemist at the Institute of Organic Chemistry and Biochemistry.

Jan Zrzavý, a biologist at the University of South Bohemia in České Budějovice, who was on the government council that drafted the reform, declined to comment, saying that transferring the discussion to an international forum would be "illcalculated and potentially harmful”.

Quirin Schiermeier 


\section{India embarks on push to become a solar power}

India's prime minister Manmohan Singh has unveiled a 30-year, US\$19-billion plan to make the country a leader in solar energy.

Announced on 3 August, the programme aims to raise installed solar capacity from its current $5 \mathrm{MW}$ to $20 \mathrm{GW}$ by $2020,100 \mathrm{GW}$ by 2030 and $200 \mathrm{GW}$ by 2050 , although a detailed road map has been drawn up to 2020 only. An autonomous solar-energy authority will be created to execute the mission, and the existing solar-energy centre near New Delhi will be upgraded to an institute that will coordinate solar-research centres across the country and promote foreign collaboration - a key feature of the plan.

Industry carrots include tax credits and priority bank loans for solar-power projects, as well as the duty-free import of raw materials. And conventional power plants with steam-driven turbines will have to generate at least $5 \%$ of their capacity from solar power.

For a longer version of this story, see http://tiny.cc/iem9|

\section{Lab worker charged with destroying protein crystals}

A former employee who allegedly destroyed US $\$ 500,000$ worth of protein crystal samples at the SLAC National Accelerator Laboratory in Menlo Park, California, was arrested and charged last week with wilfully ruining government property.

Silvya Oommachen, until July a research associate at SLAC's Joint Center for Structural Genomics (JCSG), removed $4,000-5,000$ protein crystals from three SLAC freezers at some point between 17 and 20 July, according to an FBI affidavit.

The now-useless crystals formed part of the Protein Structure Initiative, a federally funded project to expedite the discovery of atomic-level protein structures. JCSG director Ian Wilson estimates that his research team now faces a "two- to threemonth setback" to remake the protein crystals that had not yet been analysed. For a longer version of this story, see http://tinyurl.com/Ifnj43

\section{Plummeting silicon prices may boost solar sales}

The price of silicon for the solar-power industry has plunged in the past year as a result of increasing supplies and a sharp drop in demand, with the price of silicon photovoltaic panels poised to follow.

The spot price of solar-grade silicon — for immediate delivery - has fallen by roughly $77 \%$, from an average of more than US $\$ 300$ per kilogram last year to $\$ 67$ per kilogram today, according to the Londonbased consultancy New Energy Finance (see graph).

That has forced silicon and wafer suppliers to renegotiate contracts signed last year for delivery this year. Contracts signed at $\$ 150$ per kilogram have been cancelled or renegotiated at roughly $50 \%$ discount.

Even before the global financial crisis, analysts had warned that supplies would outstrip demand in 2009, with new

\section{Chikyu showcases riser drilling for deep-sea research}

\section{The first scientific ocean-floor drilling project to use a riser drill - equipment previously used in oil exploration - was completed last week. \\ The Japanese research vessel Chikyu (pictured) drilled 1,600 metres below the sea floor of the Nankai Trough, an earthquake-generating zone off the Pacific coast of Japan. \\ Riser drilling circulates mud in an extra casing around the drill to} prevent the collapse of a borehole in deep, high-pressure zones. Chikyu had already tested its riser-drilling equipment while on loan to an Australian oil company (see Nature 442, 964; 2006).

The vessel is taking a leading role in the Integrated Ocean Drilling Program, a collaboration of Japanese, US and European scientists studying rock and sediment samples to learn about Earth's structure and history. It is due to drill two more sites in the Nankai Trough.

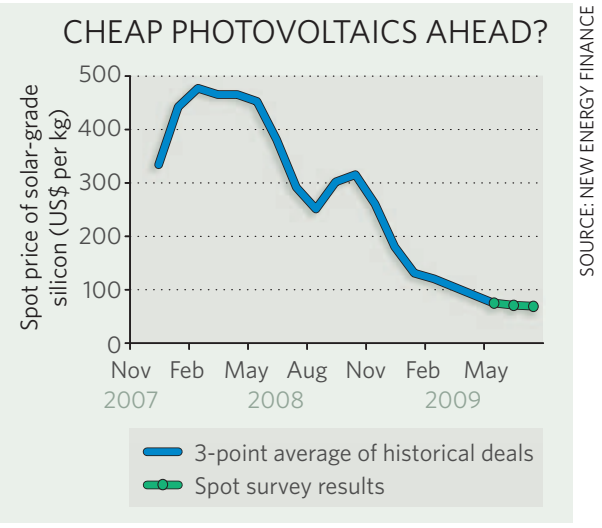

manufacturing facilities coming online at a time when countries such as Spain are scaling back solar subsidies. The good news for solar manufacturers, the consultancy reports, is that they should be able to halve the price of panels, which should spur demand.

\section{US report backs distinction between science and policy}

In setting regulatory policy, the US government should do more to separate scientific advice from policy decisions based on that advice, according to a report released on 5 August by the Bipartisan Policy Center, a non-profit body based in Washington DC established by former Democratic and Republican members of Congress.

The report recommends that regulatory agencies should post public notices that distinguish between the science and policy questions being asked. In appointing scientific advisory panels, agencies should adopt more stringent requirements about financial and professional conflicts of interest, and should be more transparent in disclosing them, it says. The report has been reviewed by the administration of President Barack Obama, who condemned the politicization of science in March, and is expected to issue guidelines on these issues later this year.

\section{Corrections}

The News story 'Biodefence lab criticized' (Nature 460, 556-557; 2009) conflated two different foot-and-mouth disease outbreaks in Britain. The 2001 outbreak required the slaughter of 6 million animals; a 2007 outbreak originated from the animal-research lab in Pirbright.

The News story 'Flu jabs urged for developing countries' (Nature 460, 156-157; 2009) incorrectly stated that Abdullah Brooks has determined that one-third of pneumonia deaths in children younger than 2 years old in Bangladesh can be attributed to the influenza virus. In fact, he has determined that about one-third of children who get influenza develop pneumonia, of whom about two-thirds are less than two years old. 